\title{
ADVANCEMENT OF FOOD PROCESSING BIOTECHNOLOGY IN DEVELOPING COUNTRIES
}

\author{
Okechukwu Q.N. ${ }^{1 *}$, Javed F. ${ }^{1}$, Ivantsova M.N. ${ }^{1}$ \\ 1) Institute of Chemical Engineering, Ural Federal University, Yekaterinburg, Russia \\ "E-mail: queencyokechukwu@gmail.com
}

Abstract: Biotechnology is an applied science which represents a blending of the principles and practice of biochemistry, genetics and microbiology. The recent breakthroughs in molecular biology have transformed biotechnology into a precision science. These developments have brought in further refinements to areas like protein chemistry, nucleic acid biochemistry, fermentation and immunology, which unfortunately are not common to developing countries.

In its broadest definition, biotechnology is any technique which uses living organisms to make products, to improve plants or animals, or to develop microbes for specific uses. Food processing which transforms raw ingredients into food makes use of various unit operations and technologies to convert relatively bulky, perishable and typically inedible raw materials into more useful shelf-stable and palatable foods or potable beverages. Processing contributes to food security by minimizing waste and losses in the food chain and by increasing food availability and marketability.

Biotechnology is being applied in ways that will affect agriculture, health, the environment, and many other aspects of science and industry in the decades to come. Most current applications are centred in the developed countries and, as a result, priorities for research and development are, in general, established by these nations.

In developing countries about 650 million of the poorest people live in rural areas where the local production of food is the main economic activity. Here, subsistence farmers eke out meager livings, and the ability to provide enough food for survival is often less than assured, the vital importance of staple crops such as rice, sweet potato and cassava cannot be overstated. Burgeoning population, especially in the developing world, will soon outstrip food production [1].

As the number of biotechnology-derived products increases, they can be expected both to coexist with conventional products and to replace them. The development of new products, and the competition and new opportunities they will create, has serious implications for developing countries. Biotechnology processes depend on sources of raw materials that can be processed into new products with a much higher value [2]. These biological resources are found naturally in many developing countries, but are at risk due to ever-increasing populations, agricultural expansion, logging, and resettlement programs. Without a sustained conservation effort, many species of plants and animals will disappear. Continued loss of biodiversity would be a serious blow to biotechnology and this situation begs for cooperation between countries that are rich in biological resources but poor in technological resources, and countries that are rich in technological resources but poor in biological resources. 
This document discusses the prospects and potential of applying biotechnology in food processing operations in developing countries. The objective is to address food security and respond to changing consumer trends in developing countries by addressing food safety issues through the incorporation of biotechnology in safe processing and preservation in food systems.

1. Edwardson, W and Graham, E. (eds). Biotech. in Dev. Countries. Int. Dev. Res. Centre Env.t and Nat. Res. Div. (1994)

2. Prakash C. S. AgBioWorld (2011)

\title{
МЕТОД ДИАГНОСТИРОВАНИЯ ПАТОЛОГИЙ СЛЕЗНОЙ ЖЕЛЕЗЫ С ПРИМЕНЕНИЕМ КОМБИНИРОВАННЫХ МЕТОДОВ ТРАНСМИССИОННОЙ И ЭМИССИОННОЙ ДИАГНОСТИКИ
}

\author{
Панкин С.В. ${ }^{*}{ }^{*}$, Сюрдо А.И. ${ }^{1,2}$, Панкин В.В. ${ }^{1,3}$, Сарычев М.Н. ${ }^{1}$, Зеленин А.В. ${ }^{4}$, \\ Агеев А.Н. ${ }^{5}$, Ободов В.А. ${ }^{6}$, Щелканов А.А. ${ }^{1}$ \\ 1) Уральский федеральный университет имени первого Президента России Б.Н. Ель- \\ цина, г. Екатеринбург, Россия \\ 2) Институт физики металлов имени М.Н. Михеева Уральского отделения Российской \\ академии наук, г. Екатеринбург, Россия \\ 3) Уральский государственный медицинский университет, г. Екатеринбург, Россия \\ 4) Областная детская клиническая больница №1, г. Екатеринбург, Россия \\ 5) Областная клиническая больница №1, г. Екатеринбург, Россия
}

6) АО Екатеринбургский центр МНТК «Микрохирургия глаза», г. Екатеринбург, Россия

*E-mail: savva.pankin@urfu.ru

\section{A METHOD FOR DIAGNOSING PATHOLOGIES OF THE LACRIMAL AND SALIVARY GLANDULAR STRUCTURES USING COMBINED TOMOGRAPHIC METHODS OF TRANSMISSION AND EMISSION DIAGNOSTICS}

Pankin S.V. ${ }^{1 *}$, Syurdo A.I. ${ }^{1,2}$, Pankin V.V. ${ }^{1,3}$, Sarychev M.N. ${ }^{1}$, Zelenin A.V. ${ }^{4}$, Ageev A.N. ${ }^{5}$, Obodov V.A. ${ }^{6}$, Shchelkanov A.A. ${ }^{1}$.

1) Ural Federal University, Yekaterinburg, Russia

2) M.N. Mikheev Institute of Metal Physics of the Ural Branch of the Russian

Academy of Sciences, Yekaterinburg, Russia

3) Ural State Medical Iniversity, Yekaterinburg, Russia

4) Regional Children's Clinical Hospital, Yekaterinburg, Russia

5) Regional clinical hospital №1, Yekaterinburg, Russia

6) IRTC Eye Microsurgery Yekaterinburg Center, Yekaterinburg, Russian Federation

Pathology of the lacrimal glands is one of the most important factors complicating the work of the visual apparatus. Assessment of morphofunctional changes of the tear-producing organ of the organ of vision allows to assess the degree of gland damage. 